\title{
Pre-hospital assistance by ambulance in the context of coronavirus infections
}

\author{
Assistência pré-hospitalar por ambulância no contexto das infecções por coronavírus \\ Asistencia pré hospitalaria em ambulância em el contexto de las infecciones por coronavirus
}

Rio de Janeiro, Brazil.

Amanda Ferreira Araujo'

ORCID: 0000-0001-7846-7119

Eric Rosa Pereira"1,,II

ORCID: 0000-0003-0202-6653

Sabrina da Costa Machado Duarte' ORCID: 0000-0001-5967-6337

Priscilla Valladares Broca' ORCID: 0000-0003-3392-910X

'Universidade Federal do Rio de Janeiro. Rio de Janeiro,

"Centro Universitário UNIABEU. Belford Roxo,

Rio de Janeiro, Brazil.

II' Fundação Técnico-Educacional Souza Marques. Rio de Janeiro, Rio de Janeiro, Brazil.

How to cite this article: Araújo AF, Pereira ER, Duarte SCM, Broca PV. Pre-hospital assistance by ambulance

in the context of coronavirus infections. Rev BrasEnferm. 2021; 74(Suppl 1):e20200657. doi: http://dx.doi.org/10.1590/0034-7167-2020-0657

Corresponding author:

Priscilla Valladares Broca E-mail: priscillabroca@gmail.com

EDITOR IN CHIEF: Dulce Barbosa ASSOCIATE EDITOR: Andrea Bernardes

Submission: 06-16-2020

Aprovado: 11-01-2020

\section{ABSTRACT}

Objective: To reflect on the safe care exercised by the pre-hospital care team by emergency ambulance in times of coronavirus infection. Method: A reflection and description of how to provide safe care to the patient and the professional during pre-hospital care in times of coronavirus infection. Results: To ensure the health of all those involved in the care, health professionals who work in pre-hospital care by emergency ambulance should use the recommended Personal Protective Equipment (PPE), such as the use of surgical masks and N95, N99, N100, PFF2 or PFF3, the use of an apron or overall, goggles and face shield, gloves and a hat. The entire team must receive training and demonstrate the ability to use PPE correctly and safely. Final considerations: The professional working in the pre-hospital care by ambulance is exposed to a series of occupational risks that need to be discussed and minimized through professional training.

Descriptors: Ambulance; Pre-Hospital Assistance; Emergency Medical Services; Coronavirus Infections; Patient Safety.

\section{RESUMO}

Objetivo: Refletir sobre o cuidado seguro exercido pela equipe de atendimento pré-hospitalar por ambulância em época de infecção por coronavírus. Método: trata-se de uma reflexão e descrição de como proporcionar um cuidado seguro ao paciente e ao profissional durante um atendimento pré-hospitalar em época de infecção por coronavírus. Resultados: para garantir a saúde de todos os envolvidos no cuidado, os profissionais de saúde que atuam no atendimento pré-hospitalar por ambulância devem fazer uso dos Equipamentos de Proteção Individual (EPI) preconizados, como o uso de máscaras cirúrgicas e N95, N99, N100, PFF2 ou PFF3, utilizar avental ou capote, óculos de proteção e protetor facial ou face shield, luvas e gorro. Toda a equipe deve receber capacitação e demonstrar capacidade de usar os EPIs de modo correto e seguro. Considerações finais: o profissional atuante no atendimento pré-hospitalar por ambulância está exposto a uma série de riscos ocupacionais que precisam ser discutidos e minimizados por meio de capacitação profissional.

Descritores: Ambulância; Assistência Pré-Hospitalar; Serviços Médicos de Emergência; Infecções por Coronavírus; Segurança do Paciente.

\section{RESUMEN}

Objetivo: Reflexionar sobre el cuidado seguro realizado por el equipo de atención prehospitalaria en ambulancia en época de infección por coronavirus. Método: se trata de una reflexión y descripción de cómo brindar un cuidado seguro al paciente y al profesional durante una atención prehospitalaria en época de infección por coronavirus. Resultados: para garantizar la salud de todos los implicados en la atención prehospitalaria, los profesionales sanitarios que trabajan en ambulancia deben utilizar el equipo de protección personal (EPP) recomendado, como el uso de mascarillas quirúrgicas N95, N99, N100, PFF2 o PFF3, delantal o capa, gafas de seguridad y protector facial o face shield, guantes y gorro. Todo el personal debe recibir formación y demostrar su capacidad para utilizar los EPPs de forma correcta y segura. Consideraciones finales: el profesional que trabaja en la atención prehospitalaria en ambulancia está expuesto a una serie de riesgos ocupacionales que deben ser discutidos y minimizados a través de la formación profesional.

Descriptores: Ambulancia; Atención Prehospitalaria; Servicios Médicos de Emergencia; Infecciones por Coronavirus; Seguridad del Paciente. 


\section{INTRODUCTION}

On January 30, 2020, the World Health Organization (WHO) declared the outbreak of the disease caused by the novel coronavirus (COVID-19) Public Health Emergency of International Concern. This alert is considered to be the highest level in the Organization, as provided for in the International Health Regulations ${ }^{(1)}$.

In December 2019 a series of unknown cases of pneumonia emerged in Wuhan, Hubei, China, with clinical presentations very similar to viral pneumonia and a thorough analysis was performed on samples taken from the lower respiratory tract that indicated a novel coronavirus subtype, named as novel Coronavirus (SARS-CoV-2)(2).

The most common symptoms experienced by people infected with COVID-19 are: fever, shortness of breath and cough. However, other non-specific or atypical symptoms may arise, such as: sore throat, diarrhea, anosmia (inability to smell) or hyposmia (decreased smell), myalgia and tiredness or fatigue ${ }^{(3)}$.

Approximately $80 \%$ of individuals recover from the disease without requiring hospital treatment ${ }^{(1)}$. However, the population at risk such as older adults, people with chronic health conditions such as hypertension, heart disease and lung disease, diabetes or cancer is of great concern. It is noteworthy that older adults with COVID-19 may present a different picture from the signs and symptoms listed above, such as, for example, the absence of fever, which can hinder the final diagnosis of the disease $\mathrm{e}^{(3)}$.

Given the above, the scientific community has carried out several researchto understand the novel Coronavirus and the best strategies for prevention and treatment of COVID-19. However, few studies are being carried out in pre-hospital care, where professionals are also daily exposed to the pathogen and who also need to take the necessary precautions to face the pandemic.

Pre-hospital care by ambulance, or mobile PHC, refers to care provided outside the hospital environment, at the accident site or where emergency care is needed (such as at home), with the purpose of assisting the patient quickly and with precision, thus increasing the chances of survival. Therefore, it represents a type of assistance capable of minimizing the damage to the health of individuals. It is noteworthy that pre-hospital care is not restricted to the mobile component, there is also a fixed component, such as emergency care units.

It is important to note that there is a continuity to the mobile pre-hospital care in hospital units, which guarantees care in its entirety respecting the clinical condition and severity of the patient. Such continuity of care can ensure that the patient is attended according to their real needs, in order to respect their diagnosis and provide safe assistance considering definitive treatment.

The most frequent types of care are of clinical nature (stroke, convulsive crisis, cardiorespiratory arrest and acute myocardial infarction), traumatic nature (accidents involving cars, motorcycles and being run over), obstetric nature (births, eclampsia and hemorrhages) and psychiatric nature (psychotic breaks).

The mobile PHC team consists of doctors, nurses, nursing technicians and drivers/rescuers. Such professionals need to present attributes such as: competence, motor skills, creativity and sensitivity ${ }^{(4)}$. These characteristics may minimize the risks to which professionals are exposed during the care of patients with suspected/confirmed infection by Coronavirus. Sometimes, the emergency team does not know the patient's real clinical situation, which can cause stress and anxiety, or lead to insufficient, negligent care that does not meet the victim's real needs due to the risks of contamination.

Where there is health care, professionals need to exercise care based on safety. Safe care implies making evidence-based clinical decisions to maximize the individual's health outcomes and minimize the potential for harm, that is, it must be practiced harmless to the patient. In pre-hospital mobile care, decision making is quick and the professional is susceptible to a chain of errors and incidents, which can be related to the complexity and diversity of the cases and scenarios found ${ }^{(5)}$. Thus, the mobile PHC professional should always seek safe care, with a technicalscientific basis acquired through professional training.

With the COVID-19 pandemic, prehospital care began to assist patients with suspected or confirmed diagnosis of the disease, with an increase in the number of calls, which can cause an overload on the demand for the service and directly impact patient safety, with regard to the time/response between the activation and the help and the care provided.

\section{OBJECTIVE}

To reflect on the safe care provided by the emergency mobile pre-hospital care team in the context of the COVID-19 pandemic.

\section{THE POSSIBLE RISKS IN EMERGENCY MOBILE PRE-HOSPI- TAL CARE FOR PATIENTS WITH SUSPECTED/CONFIRMED DIAGNOSIS OF COVID-19}

All protection measures to prevent and control the infection need to be implemented and followed, in any care environment, and mobile PHC is no different. These protective attitudes are important, as there is research and reports that indicate that individuals can transmit the COVID-19 virus, even though they are asymptomatic.

In this sense, communication among the health team is of fundamental importance as it is a practical example that involves patient safety. The improvement of communication among health professionals is part of one of the international goals of the Ministry of Health, as poor communication can cause health incidents more frequently, such as unreadable content in the attendance records and lack of shared information in the communication during the case transfer from the mobile prehospital services to the intrahospital services.

And it is also necessary to take into account the communication between the Regulatory central and the team that will perform the service, as the information shared needs to be as accurate as possible so that professionals are aware and prepare in the best way to perform the service, mainly in a suspected or confirmed case of COVID-19.

To systematize this communication process, there are some tools that are used in an attempt to organize and streamline the transfer of care and that can be used in the communication from the mobile pre-hospital to the intra-hospital ${ }^{(6)}$

a) SBAR - Situation, Background, Assessment and Recommendations; 
b) MIST - Mechanism, Injuries, Symptoms, Treatment;

c) IMIST-AMBO - Identification/patient, Mechanism of injury/medical complaint, Injuries/information related to the compliant, Signs And Symptoms Including GCS and vital signs, Treatment Given And Trends Noted, Allergies, Medications/patient's regular medications, Background history/patient's past.

d) History, Other Information - scene, social, valuables, advanced directives, Family informed;

e) ATMIST - name (name, age and sex), Time (estimated time of arrival at the indicated health unit and time of the incident), Mechanism (medical/historical complaint/injury mechanism), Injuries (investigations/injuries observed or suspected), Symptoms (Symptoms presented/to inform if the patient has improved or worsened during the journey), Treatment (treatment offered).

Emergency MobilePHC professionals need to have a different look at the most common symptoms of COVID-19, such as fever, cough and shortness of breath, but without forgetting nonspecific symptoms, which can be important drivers for the care of patients with the novel Coronavirus ${ }^{(3)}$.

The care to be provided to patients with COVID-19 will be different from those offered in the intra-hospital environment, since the mobile pre-hospital is faced with complex and poorly controlled environments, and professionals can be considered members of the novel Coronavirus risk group ${ }^{(7)}$. In this context, it is worth highlighting the difficulty of access to communities, in which, many times, handling stretchers, boards and other equipment require different strategies. Thus, in mobile $\mathrm{PHC}$, the team needs to be concerned with the whole context involved: security of the scenario, high risks of falling due to poor conservation of alleys, risk to the occupational health of professionals, among others.

In addition, ambulances do not have sinks or devices for washing hands with soap and water, nor are there these types of resources in adequate mode in the attendance locations. Thus, in the pocket material of these professionals, it is necessary to have a $70 \%$ alcohol hand sanitizer gel bottle, which is easily accessible, so that they can use it whenever they need it.

As a preventive measure to minimize the possible risks of contamination, it is important that an exclusive team remains in a separate area to assist suspected or confirmed cases of coronavirus infection. For this, it is also important for professionals to have an additional uniform available for the exchange during the service, if necessary, and men should keep their beard trimmed ensuring greater adherence of the mask to the face.

It should also be noted that the guarantee of a definitive airway, for example, with orotracheal intubation, becomes a challenge for the team, due to the restricted physical space of the ambulance compared to hospitals, which can increase the possible risk of contamination of these professionals. Therefore, alternatives for $\mathrm{O}_{2}$ supplementation are recommended in patients with suspected or confirmed coronavirus infection, such as the $\mathrm{O}_{2}$ nasal cannula, non-rebreather mask and highflow nasal cannula ${ }^{(3,8)}$.

\section{PREVENTION MEASURES IN EMERGENCYMOBILE PRE- HOSPITAL CARE AGAINST COVID-19}

There is still much to know and learn about the novel coronavirus, and the investigations do not stop. However, it is possible to state that transmission occurs from person to person through respiratory droplets and through direct or indirect contact through contaminated hands, objects or surfaces ${ }^{(9)}$. It is essential to emphasize that in PHC mobile, all patients who are unconscious and without the possibility of obtaining information about it, should be considered suspected cases of COVID-19(10).

To ensure occupational health, health professionals working in emergency mobile PHC should make use of the recommended Personal Protective Equipment (PPE), following the recommendations of the Ministry of Health, such as the use of surgical masks and N95, N99, N100, PFF2 or PFF3, the use of an apron or overall, goggles and face shield, gloves and a hat ${ }^{(3)}$. The entire team must receive training and demonstrate the ability to use PPE correctly and safely.

The driver/rescuer, when working only driving the vehicle, must keep the distance and use a fabric mask, highlighting that there is a partition between the driver's space and the patient's location $^{(3)}$. However, if the driver/rescuer assists with care, he will need to use the same equipment as other professionals. If the ambulance does not have a partition between the driver's space and the patient's location, it will be necessary to use a surgical mask and N95, N99, N100, PFF2 or PFF3 ${ }^{(3)}$. It is worth remembering that all professionals involved need to perform proper hand hygiene with $70 \%$ alcohol hand sanitizer gel or soap and water whenever possible.

When transporting the patient using mechanical ventilation, it is recommended that the entire service team is wearing an N95 mask, or equivalent, due to the risk of aerosolization. In addition, it is recommended to use mechanical ventilation early with a microprocessor device that contains expiratory filters. If not, HEPA, HMEF or HME filters should be used, which filter bacteria and viruses. The filters are changed according to the time indicated by the filter manufacturers ${ }^{(3)}$.

The symptomatic patient for the novel coronavirus must use a surgical mask, in addition to ensuring the ventilation of the environment during transport and care through exhaust air conditioning, which allows for adequate air exchange, or to keep the windows open ${ }^{(3)}$. It is essential prior notification of the health service to where the suspected or confirmed case will be forwarded.

At the end of each transport it is necessary to clean and disinfect all internal surfaces of the vehicle. Disinfection can be done with $70 \%$ alcohol, sodium hypochlorite or another disinfectant indicated for this purpose and following the standard operating procedure defined for cleaning and disinfecting the vehicle and its equipment and performing hand hygiene with water and liquid soap or alcoholic preparation for the hands, after cleaning the vehicle and removing the PPE used ${ }^{(3)}$. It is recommended that the emergency units have an area to carry out the ambulance terminal and concurrent cleaning before it returns to the base and that the ambulance doors and windows are kept open during the internal cleaning of the vehicle. 
In addition to these measures, some other recommendations are necessary, such as: all PPE must be removed immediately after leaving the place where the patient was destined; establish a reception area for patients brought by ambulances in order to guarantee the inflow and quick release of the mobile PHC team; the restriction of companions, with the exception of minors under 18, physically disabled and those with walking difficulties.

\section{Study limitations}

The study has the limitation of not having specific national and international publications on the theme, which aroused the authors interest in writing about the subject. Because of this, throughout the writing of the reflection, the references used had subjects close to the approached together with the professional experience of the authors.

\section{Contributions to the Nursing and Health field}

The present study discloses and reflects on some conducts that can collaborate for assistance, in the pre-hospital mobile environment, which guarantees the protection and prevention against infections of the professional and the patient and, thus, guarantees adequate and safe health care. It also contributes to the identification of barriers to this type of care, so that one can intervene early to avoid errors and incidents. In this sense, there is a need for further studies in the area to encourage the exercise of health professionals.

\section{FINAL CONSIDERATIONS}

This is a reflection on security in mobile pre-hospital care in the context of the Covid-19 pandemic. The specificities of care outside the hospital context stand out, considering all the complexities involved, ranging from the lack of a suitable place for hand washing to care in open scenarios such as streets and communities.

Given this multifaceted context, the professional working in mobile PHC is exposed to a series of occupational risks that need to be discussed and minimized through professional training, use of appropriate PPE and standards that enable the safety of everyone involved.

Thus, this reflection seeks to amplify the discussion on safety for both professionals and patients in mobile $\mathrm{PHC}$, in the midst of thenovel coronavirus pandemic, giving visibility to a theme that is often little explored, and that requires intervention studies capable of producing impact, envisioning improvements in the quality of care provided.

\section{REFERENCES}

1. Pan American Health Organization (PAHO). World Health Organization (WHO). Folha informativa - COVID-19 (doença causada pelo novo coronavírus). [Internet] Washington;2020 [cited 2020 Jun 01] Available from: https://www.paho.org/bra/index.php?option=com_content\& view $=$ article\&id $=6101$ :covid 1 \&\&ltemid $=875$

2. Huang C, Wang Y, Li X, Ren L, Zhao J, et al. Clinical features of patients infected with 2019 novel coronavirus in Wuhan, China. Lancet. 2020;395(10223):497-506. doi: 10.1016/S0140-6736(20)30183-5

3. Ministério da Saúde (BR). Agência Nacional de Vigilância Sanitária, Nota Técnica GVIM/GGTES/ANVISA No 04/2020 (atualizada em 08 de Maio de 2020). Orientações para os serviços de saúde: medidas de prevenção e controle que devem ser adotadas durante a assistência aos casos suspeitos ou confirmados de infecção pelo novo Coronavírus (SARS-COV-2). [Internet] Brasília: Ministério da Saúde, 2020[cited 2020 Sep 03]. Available from: http://portal.anvisa.gov.br/notas-tecnicas

4. Ministério da Saúde (BR). Portaria n ${ }^{\circ}$ 2048, de 5 de novembro de 2012. Aprovar, na forma do Anexo desta Portaria, o Regulamento Técnico dos Sistemas Estaduais de Urgência e Emergência. [Internet] Brasília: Ministério da Saúde, 2002[cited 2020 Sep 03]. Available from: https:// bvsms.saude.gov.br/bvs/saudelegis/gm/2002/prt2048_05_11_2002.html

5. Pereira EP, Rocha RG, Monteiro NCA, Oliveira AB, Paes GO. Risco de infecção associado ao cuidado no atendimento pré-hospitalar: impactos para a segurança do paciente. Res Soc Develop 2020;9(8):e588985846. doi: 10.33448/rsd-v9i8.5846

6. ShahY, Alinier, G, Pillay Y. Clinical handover between paramedics and emergency department staff: SBAR and IMIST-AMBO acronyms. Int Paramedic Pract. 2016;6(2):37-44. doi: 10.12968/ippr.2016.6.2.37

7. Department of Labor (US). Occupation safety and health administration: control and prevention[Internet]. Estados Unidos da América; 2020[cited 2020 Sep 03]. Available from: https://www.osha.gov/SLTC/covid-19/controlprevention.html

8. Associação Brasileira de Medicina de Emergência (ABRAMEDE); Associação Médica Brasileira (AMB). Recomendações sobre Oxigenioterapia no Departamento de Emergência para Pacientes Suspeitos ou Confirmados de COVID-19[Internet]. 2020[cited 2020 Sep 03]. Available from: http://abramede.com.br/noticias/

9. World Health Organization (WHO). Modes of transmission of virus causing COVID-19: implications for IPC precaution recommendations [Internet]. Geneva; 2020[cited 2020 Sep 03]. Available from: https://www.who.int/news-room/commentaries/detail/ modes-of-transmission-of-virus-causing-covid-19-implications-for-ipc-precaution-recommendations

10. Associação Brasileira de Medicina de Emergência (ABRAMEDE); Conselho Federal de Enfermagem (COFEN) e Colégio Brasileiro de Enfermagem em Emergência (COBEEM). Recomendações para o atendimento de pacientes suspeitos ou confirmados de infecção pelo novo coronavírus (sars-cov-2) pelas equipes de atendimento pré-hospitalar móvel[Internet]. 2020[cited 2020 Sep 03]. Available from: http:// abramede.com.br/noticias/ 